\title{
GROWTH SUPRESSION OF PLANT PATHOGENIC FUNGI USING BRYOPHITE EXTRACTS
}

\author{
SUPRESSÃO DE CRESCIMENTO DE FUNGOS PATOGÊNICOS DE PLANTAS \\ USANDO EXTRATOS DE BRIÓFITAS
}

\author{
Nedeljko LATINOVIC ${ }^{1}$; Marko S. SABOVLJEVIC ${ }^{2}$; Milorad VUJICIC ${ }^{2}$; \\ Jelena LATINOVIC ${ }^{1}$; Aneta D. SABOVLJEVIC ${ }^{2}$ \\ 1. University of Montenegro, Biotechnical Faculty, Podgorica, Montenegro. nlatin@ucg.ac.me; 2. University of Belgrade, Institute of \\ Botany and Botanical Garden, Faculty of Biology, Belgrade, Serbia
}

\begin{abstract}
Chemicals are often used in attempts to control diseases caused by plant pathogenic fungi during food production. However, chemicals can have adverse effects not just on food, but they also remain active for a long time within ecosystems, and thus are not environmentally friendly. Therefore, development of bio-treatment and avoiding use of chemicals are urgently needed. With the aim of studying and developing new environmentally-friendly treatments, we tested extracts from selected bryophyte species (Porella platyphylla, Cinclidotus fontinaloides and Anomodon viticulosus) on five plant pathogenic fungi under controlled conditions. The fungi (Botryosphaeria dothidea, Phomopsis viticola, Calosphaeria sp., Colletotrichum acutatum and Monilinia laxa) were selected based on common diseases they cause on fruits and grapevine. They were isolated in cultures and treated with bryophyte extracts. Bryophyte extracts were shown to be effective in suppression of certain plant pathogenic fungi growth and to have a huge potential in development of novel biotechnological treatments and biofungicides. The best results were achieved in inhibition of B. dothidea, P. viticola and Calosphaeria sp.
\end{abstract} chemistry.

KEYWORDS: Plant fungal pathogens. Fruit and grapevine diseases. Moss. Liverworts. Natural

\section{INTRODUCTION}

Bryophytes are a huge group of terrestrial plants (ca. 20000 species) that have many interesting peculiarities - ecological, physiological, developmental or constitutional (SABOVLJEVIC et al., 2016). It is widely accepted that bryophyte species are seldom used as a food source but are also not harmed by other organisms. This can be due to their special chemical constituents (WOLTERS1964, SABOVLJEVIC et al., 2017). Indeed, bryophyte material in herbaria are rarely damaged by insects or overgrown with fungi. There are many reports of antiviral, antibacterial and antifungal activities of bryophytes (VAN HOOF1981, SABOVLJEVIC et al., 2006, 2010, 2011). However, recently there have been reports of the growth of fungi on the bryophyte species named bryophilous fungi (DÖBBELER 1997). Thus, a taxonomically diverse suite of fungi interacts with bryophytes as pathogens, parasites, saprobes, and commensals (DAVEY; CURRAH 2006). However, there are so few data on the interaction between bryophytes and fungi that many new and interesting phenomena emerged (e.g. reports on ploidy level changes in bryophyte caused by fungal extracts by Goga et al. (2018)).

Plant pathogenic fungal diseases can cause rather huge problems especially in growing crops or any kind of monocultures and each year many chemicals are used to combat fungal diseases (ELAD et al. 1980; COLLA et al. 2012). However, these are not always effective and need to be applied successively, depending on plant developmental stage as well as climate or weather conditions. Apart, this treatment is not environmental friendly, but it is widely applied in food production. The chemical accumulation in natural ecosystems causes many other problems and a search for biotreatments of fungal plant diseases is urgently needed (GAMLIEL et al. 2000; GRUETSKY et al. 2002; EYLES et al. 2015).

In order to evaluate bryophyte-fungi relationships and to examine the potential of bryophytes in pathogenic fungi suppression, the effects of extracts from selected bryophyte species on five fungal pathogens that cause common fruit and grapevine diseases were studied. Isolates of the following pathogenic fungi were used: Botryosphaeria dothidea (Moug. ex Fr) Ces. \& De Not, causing twig, branch and stem cankers, tip and 
branch dieback, fruit rot of many woody plants; Phomopsis viticola (Sacc.) Sacc., a pathogen of grapevine causing Phomopsis cane and leaf spot disease; Calosphaeria sp. causing Calosphaeria canker in trunks of stone fruits; Colletotrichum acutatum Simmonds, causing anthracnose in a very wide host range, but economically most important regarding strawberries; Monilinia laxa (Aderhold \& Ruhland) Honey, the causal agent of brown rot of stone and pome fruits, that is economically more important regarding stone fruits. So, we tested extracts from these selected bryophyte species on five plant pathogenic fungi under controlled conditions.

\section{MATERIAL AND METHODS}

\section{Bryophyte sampling}

Three bryophyte species were sampled randomly to test their chemical content activity. One leafy liverwort (Porella platyphylla (L.) Pfeiff.) was sampled near Morača monastery (Montenegro) on $12^{\text {th }}$ February 2017. Additionally, two mosses, one aquatic (Cinclidotus fontinaloides (Hedw.) P. Beauv.) and one terrestrial (Anomodon viticulosus (Hedw.) Hook. \&Tayl.) were collected in Rijeka Crnojevića (Montenegro) on $8^{\text {th }}$ February 2017, by the authors. The vouchers were deposited in BEOU bryological collection (Belgrade University Herbarium, Serbia). This bryophyte material was used for preparation of extracts after short storage at room temperature.

\section{Extract assay}

The extracts were made by $5 \mathrm{~g}$ of room-dried plant material ground into a powder. A total of $50 \mathrm{~mL}$ of solvent $(42 \mathrm{~mL}$ of methanol and $8 \mathrm{~mL}$ of water) was added to powder. The composite achieved was evaporated until it was dry and the powdery residue was dissolved into $5 \mathrm{~mL}$ of methanol (HPLC grade). The bryophyte extract produced was used to test fungal growth inhibition.

\section{Fungal isolates and culturing}

All fungi used in the experiment were isolated from diseased plant material from different localities in Montenegro. B. dothidea was isolated from rotten olive fruits; isolate of $P$. viticola was taken from infected grapevine cane; Calosphaeria sp. was obtained from sweet cherry trees; $C$. acutatum isolate was obtained from diseased strawberry fruits and $M$. laxa was isolated from peach fruits with brown rot symptoms. All isolates were maintained in the fungal collection in plant pathology laboratory of Biotechnical Faculty in Podgorica (Montenegro).

\section{Experimental design}

The influence of bryophyte extracts on mycelial growth of selected plant pathogenic fungi was studied according to a modified method described by Grgic et al. (2016). The experiment was set up in Petri dishes $(90 \mathrm{~mm})$ poured with 20 $\mathrm{mL}$ of potato dextrose agar (PDA). Sterile filter paper (diameter of $6 \mathrm{~mm}$ ) was placed in centre of the Petri dishes while four fungal fragments $(\varnothing 6$ $\mathrm{mm}$ ) were placed crosswise at a distance of $5 \mathrm{~mm}$ from the edge of Petri dish. Each bryophyte extract was pipetted in amounts of 5,10 and $15 \mu \mathrm{L}$ and deposited on filter paper while distilled water was used as a control. The experiment was set up in two replicates. The cultures containing fungal fragments were incubated at $25^{\circ} \mathrm{C}$ in darkness. Inhibition of mycelial growth was evaluated when mycelium of each fungus was developed until it reached the filter paper in the centre of the Petri dish or very close to it. The distance from filter paper with bryophyte extract to developed fungal mycelium was measured and used to calculate the suppression rate caused by bryophyte extract on each fungus.

\section{Statistics}

Data analysis was carried out using the statistical program Origin 6.1. Results are presented as mean values, evaluated by technical repetition. The distances between filter paper with bryophyte extract and fungal mycelium as rating criteria of the growth inhibition effect were statistically analysed by analysis of variance, and mean values were compared using LSD test. If their difference was greater than the LSD test, they were considered statistically significant.

\section{RESULTS AND DISCUSSION}

The bryophyte extracts obtained showed different effects on selected fungi. The results obtained are presented in Table 1 while inhibitory effects of bryophyte extract to each fungus are given in the separate figure.

$B$. dothidea was affected by growth suppression by all three bryophyte extracts applied in certain dosage (Figure 1). The extract of $P$. platyphylla inhibited fungal growth when applied at $15 \mu \mathrm{L}$, while extracts of $A$. viticulosus and $C$. fontinaloides achieved statistically significant inhibitory effects at a dose of $5 \mu \mathrm{L}$. 
Table 1. Inhibition zone $(\mathrm{cm})$ as distances between filter paper with bryophyte extract and fungal mycelium

\begin{tabular}{|c|c|c|c|c|c|c|c|c|c|c|c|}
\hline & \multirow{3}{*}{$\begin{array}{c}\text { Bryophyte } \\
\text { Control }\end{array}$} & \multirow{2}{*}{\multicolumn{3}{|c|}{$\begin{array}{c}\text { Porella } \\
\text { platyphylla }\end{array}$}} & \multicolumn{3}{|c|}{$\begin{array}{c}\text { Anomodon } \\
\text { viticulosus }\end{array}$} & \multicolumn{3}{|c|}{$\begin{array}{c}\text { Cinclidotus } \\
\text { fontinaloides }\end{array}$} & \multirow[b]{3}{*}{ LSD } \\
\hline & & & & & \multicolumn{3}{|c|}{ Amount of extract } & \multicolumn{3}{|c|}{ Amount of extract } & \\
\hline Fungi & & $5 \mu \mathrm{L}$ & $10 \mu \mathrm{L}$ & $15 \mu \mathrm{L}$ & $5 \mu \mathrm{L}$ & $10 \mu \mathrm{L}$ & $15 \mu \mathrm{L}$ & $5 \mu \mathrm{L}$ & $10 \mu \mathrm{L}$ & $15 \mu \mathrm{L}$ & \\
\hline B. dothidea & 0.31 & 0.53 & 0.44 & 0.60 & 0.66 & 0.39 & 0.50 & 0.61 & 0.34 & 0.50 & 0.243 \\
\hline P. viticola & 0.00 & 0.25 & 0.36 & 0.30 & 0.36 & 0.25 & 0.34 & 0.19 & 0.14 & 0.15 & 0.244 \\
\hline Calosphaeria sp. & 0.00 & 0.09 & 0.19 & 0.10 & 0.03 & 0.18 & 0.13 & 0.20 & 0.11 & 0.11 & 0.165 \\
\hline C. acutatum & 0.64 & 0.61 & 0.83 & 1.15 & 0.65 & 0.79 & 0.50 & 0.90 & 0.43 & 0.61 & 0.309 \\
\hline M. laxa & 0.30 & 0.26 & 0.31 & 0.14 & 0.51 & 0.06 & 0.08 & 0.31 & 0.10 & 0.30 & 0.338 \\
\hline
\end{tabular}

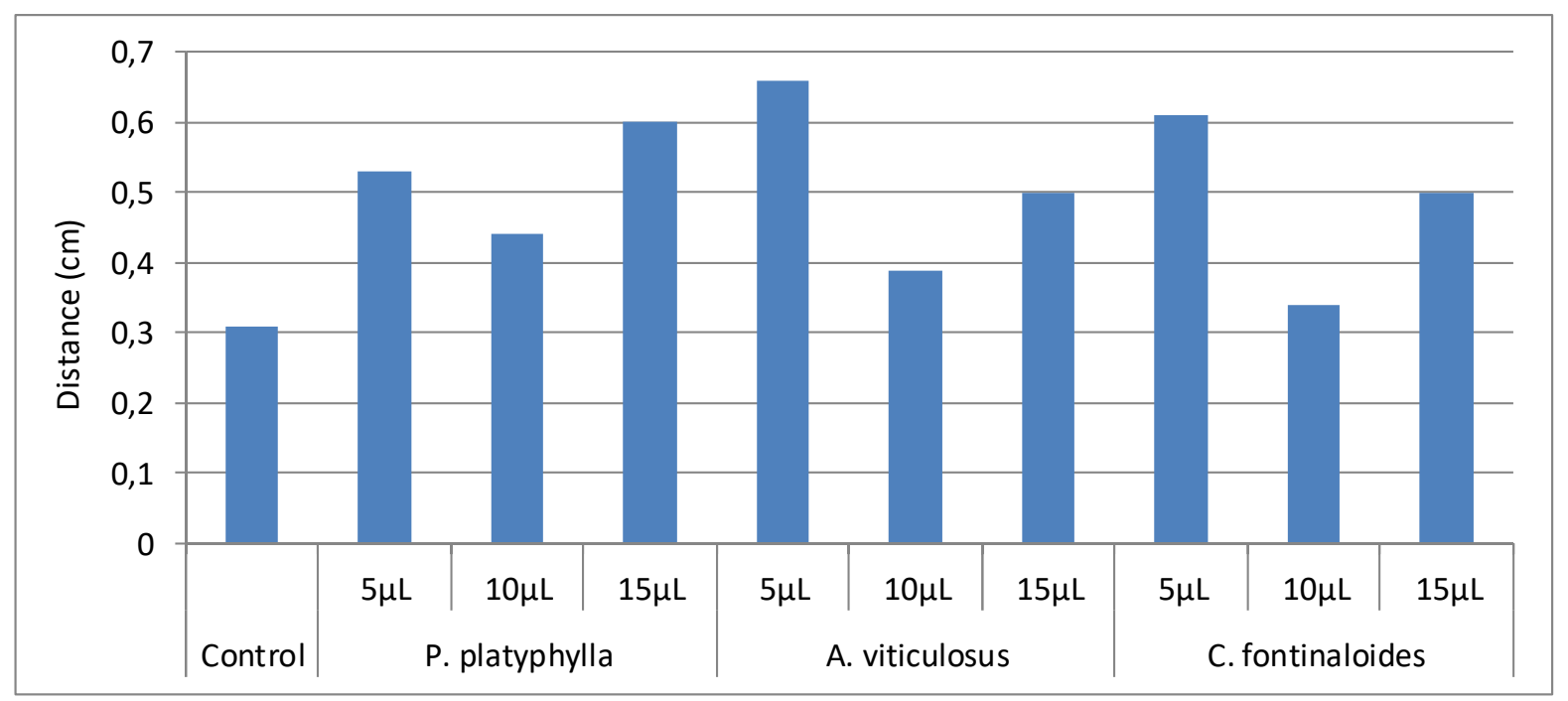

Figure 1. Influence of different bryophyte extracts and dosage on growth inhibition of B. dothidea mycelium.

Statistically significant inhibition of $P$. viticola was recorded when treated with $P$. platyphylla and A. viticulosus extracts in all three doses tested. Among the dosages used there were no statistically significant differences in achieved fungal inhibition. On the other hand, extract of $C$. fontinaloides exhibited no inhibitory activity no matter the dosage applied (Figure 2).

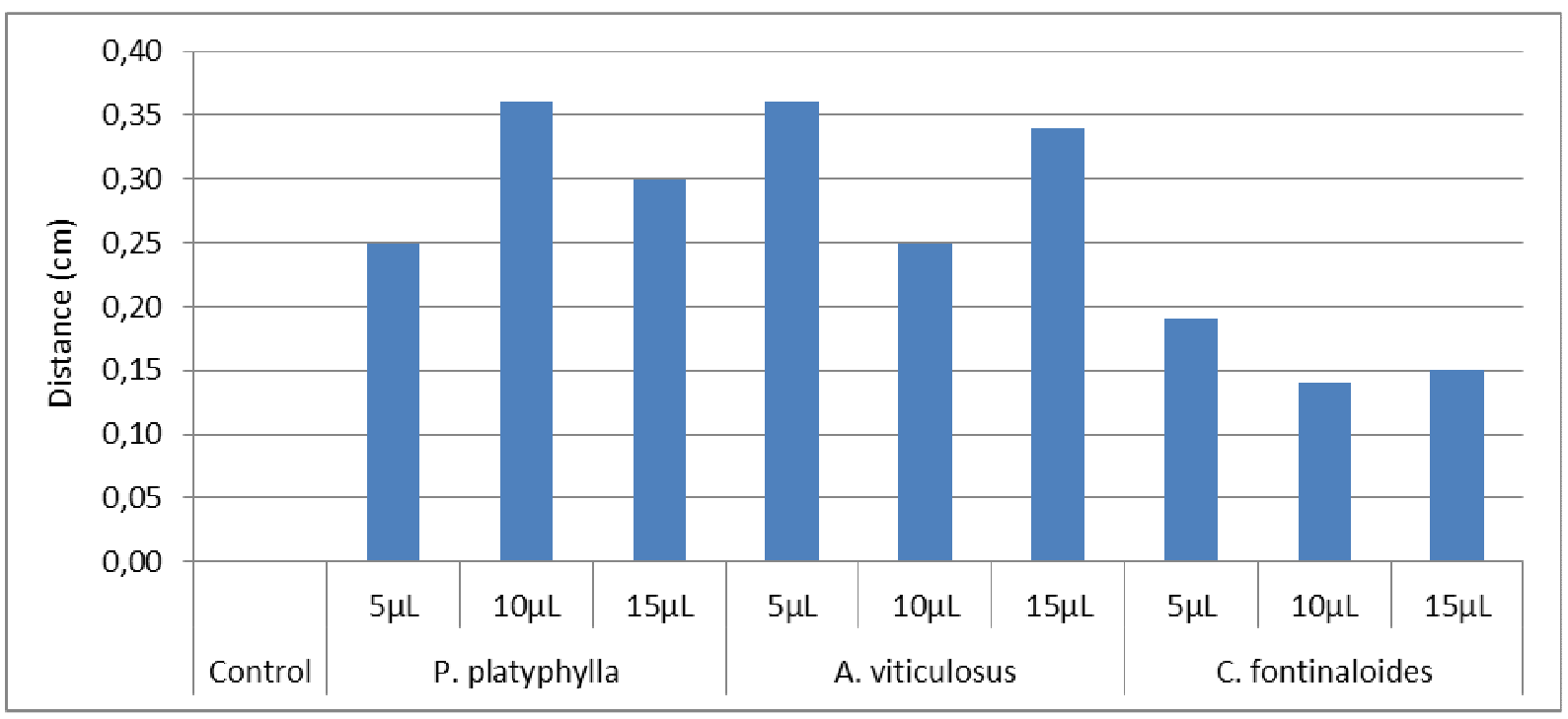

Figure 2. Influence of different bryophyte extracts and dosage on growth inhibition of $P$. viticola mycelium 
Mycelial growth of Calosphaeria sp. was suppressed when all three bryophyte extracts were applied in certain amount (Figure 3). Inhibition of the fungus was recorded when P. platyphylla and $A$. viticulosus extracts were applied at $10 \mu \mathrm{L}$ while the extract of $C$. fontinaloides suppressed fungal development at $5 \mu \mathrm{L}$.

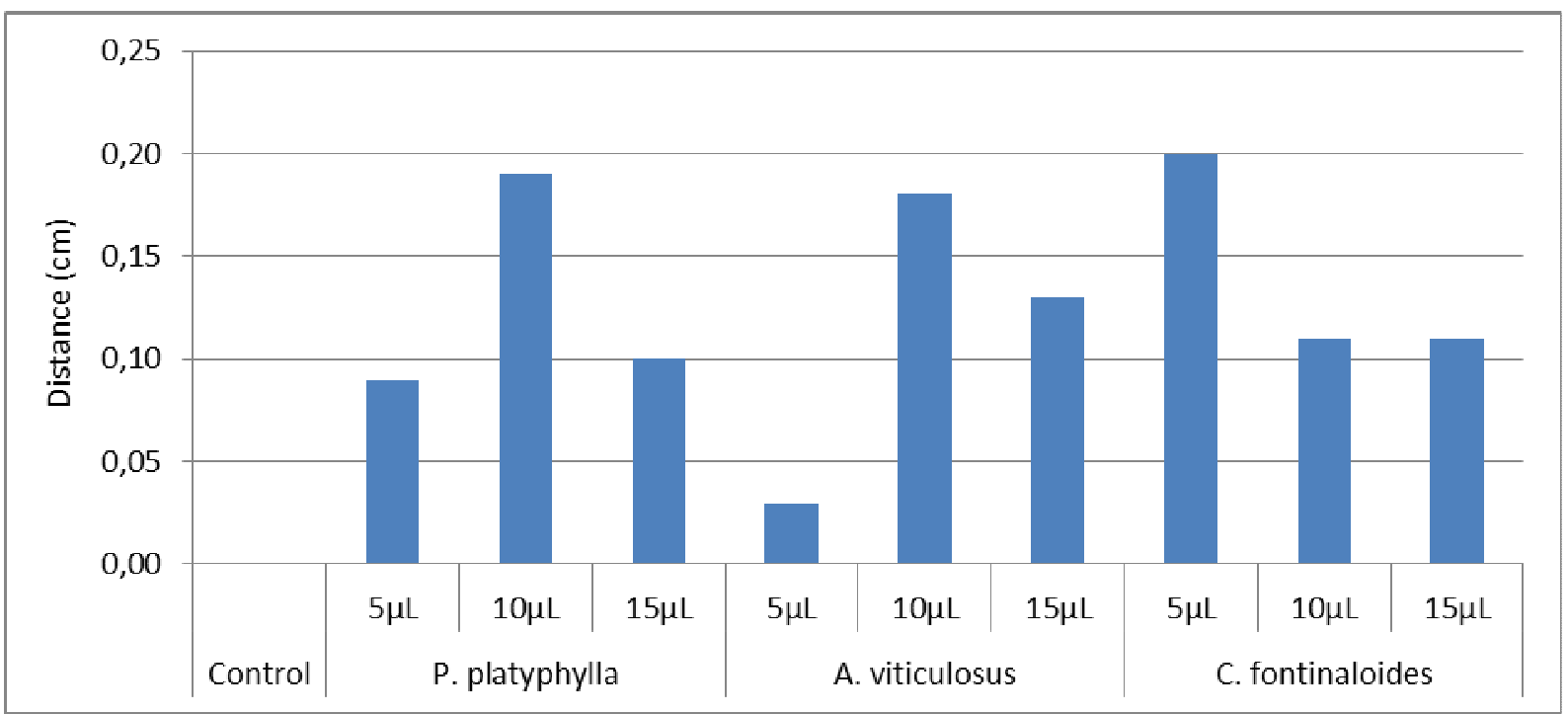

Figure 3. Influence of different bryophyte extracts and dosage on growth inhibition of Calosphaeria sp. mycelium

C. acutatum mycelium was suppressed when extract of $P$. platyphylla was applied at the highest dosage of $15 \mu \mathrm{L}$. In other dosages and other bryophyte extracts there were no statistically significant differences compared to control (Figure 4).

The extracts of bryophytes applied to mycelium of M. laxa showed no inhibitory effects in any of the applied dosages (Figure 5).

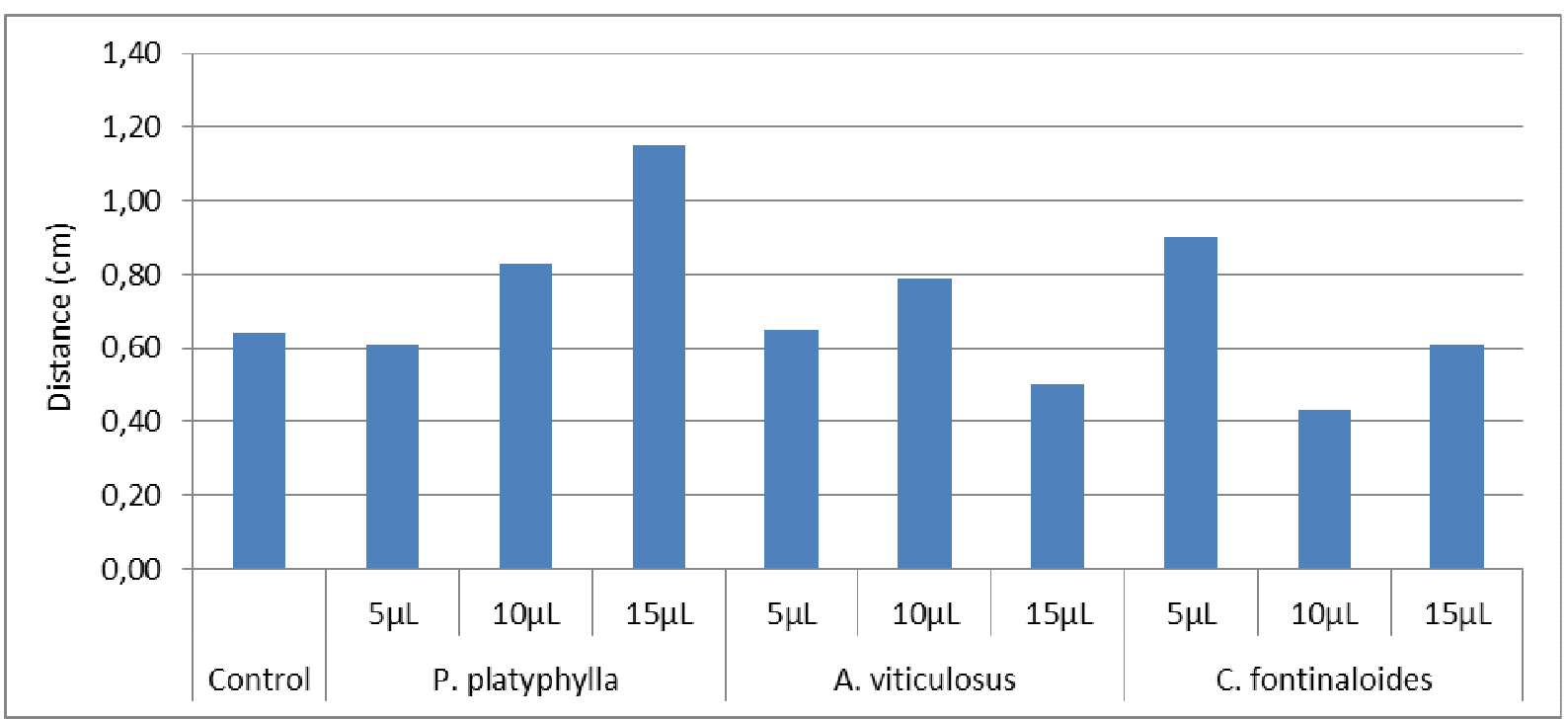

Figure 4. Influence of different bryophyte extracts and dosage on growth inhibition of $C$. acutatum mycelium 


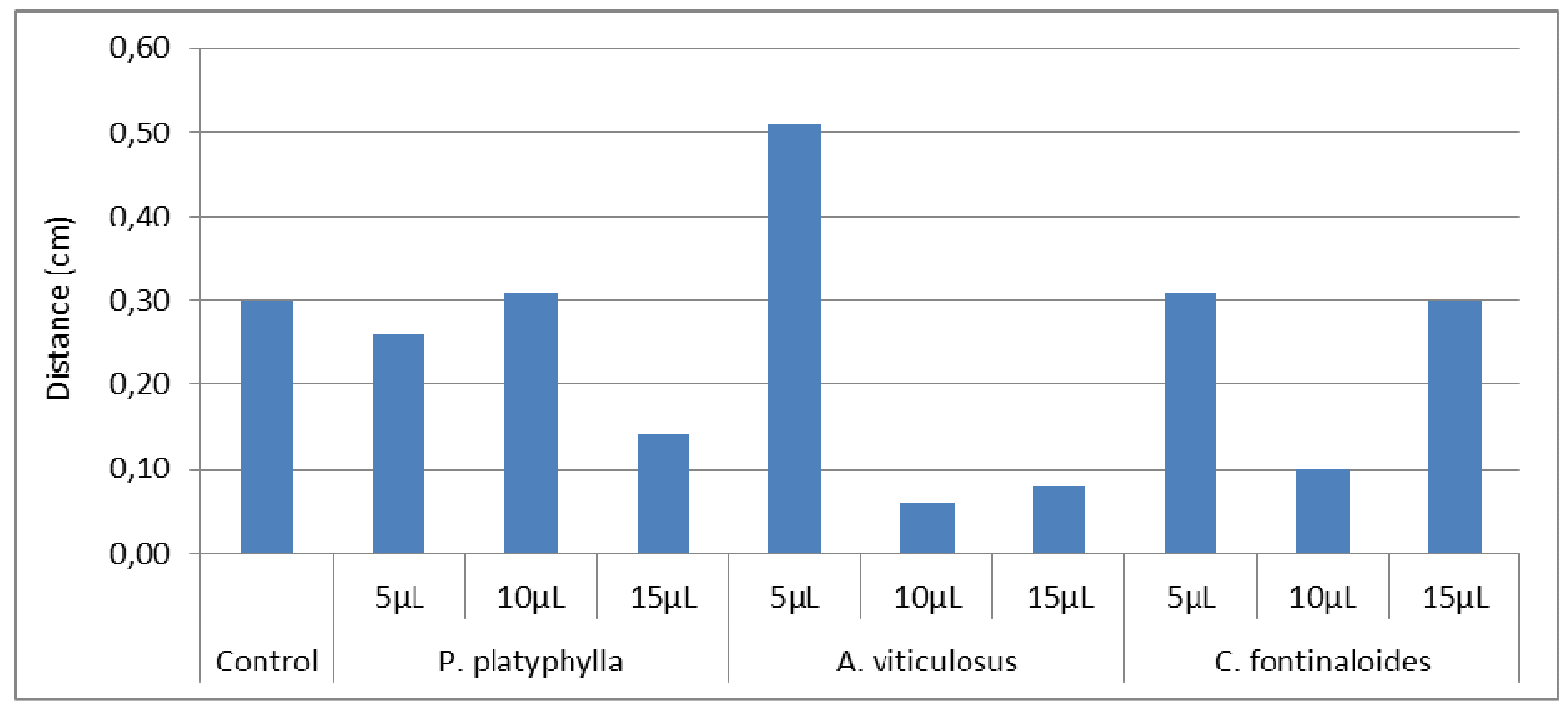

Figure 5. Influence of different bryophyte extracts and dosage on growth inhibition of M. laxa mycelium

It is generally accepted that bryophytes possess significant activity against plant pathogenic fungi, though data on these remained rather limited. Srivastava (2015) reported that moss Funaria hygrometrica extracts show activity against Alternaria species causing diseases of garden plants, field crops, vegetables, and ornamentals. Also, some bryophyte extracts inhibited development of Botrytis cinerea (grey mould), Phytophthora infestans (late blight of tomatoes) and Blumeria graminis (powdery mildew of wheat) in in vitro experiments carried out by Tadesse et al. (2003). A bryophyte aqueous extract was found to be effective against seven postharvest phytopathogens tested and reported by Alam et al. 2011. Shivom Singh et al. (2010) studied antimicrobial properties of a liverwort extracts which showed bioactivity against several important fungal plant pathogenic species, namely Rhizoctonia solani, Sclerotium rolfsii, Fusarium oxysporum and Tilletia indica.

There are only a few records about antimicrobial activity of the three bryophyte species in this study. The extracts of P. platyphylla showed antimicrobial effects on some gram-positive bacteria (BEIKE et al. 2010), while Glime (2017) reported its antifungal properties.

Ethanol extract of $C$. fontinaloides was observed to have significant antibacterial effect (YAYINTAS et al. 2017) but no antifungal activity was tested. In regard to A. viticulosus, to the best of our knowledge there are no data published about its antimicrobial activity as stated also by Vollar et al. (2018).
Our findings present valuable information within the area studied since there are no data on antifungal effects of the three moss species to the selected plant pathogenic fungi.

\section{CONCLUSIONS}

The results are the first ones in Montenegro on efficacy of selected bryophyte extracts in supressing growth of plant pathogenic fungi $(B$. dothidea, P. viticola, Calosphaeria sp., C. acutatum and $M$. laxa). The inhibitory effects of tested bryophyte extracts indicate the potential as a source of natural active substances in management of certain fungal plant pathogens.

The best antifungal activity was achieved by $P$. platyphylla and $C$. fontinaloides extracts, which were the most effective on $P$. viticola mycelial growth. Significant results were also obtained by extracts of $P$. platyphylla, C. fontinaloides and A. viticulosus in some dosages applied to suppress mycelial growth of $B$. dothidea and Calosphaeria sp.

Achieved results could be important for development of environmentally safe alternatives in integrated plant disease management.

\section{ACKNOWLEDGEMENTS}

This study was supported by SerbiaMontenegro bilateral project "Biopesticides: effect of moss extracts in control of fruits and grapevine diseases".

RESUMO: Fungos fitopatogênicos são controlados com produtos químicos para combater doenças causadas por eles durante a produção de alimentos. Tais produtos são ruins não apenas para a alimentação, mas 
também podem permanecer por muito tempo nos ecossistemas, portanto, não são ecologicamente corretos. Desta forma, os biotratamentos e a prevenção de usos químicos são urgentemente necessários no futuro próximo. Com o objetivo de estudar e desenvolver nova alternative decontrole de doenças de plantas, testamos os extratos de espécies de briófitas selecionadas (Porella platyphylla, Cinclidotus fontinaloides e Anomodon viticulosus) em cinco fungos fitopatogênicos (Botryosphaeria dothidea, Phomopsis viticola, Calosphaeria sp., Colletotrichum acutatum e Monilinia laxa) em condição controlada. Estes fungos, selecionados com base nas doenças que causam em frutos e videiras, foram isolados em culturas puras e tratados com os respectivos extratos de briófitas. Os extratos de briófitas demonstraram ser eficazes na supressão de certos fungos fitopatogênicos e têm um enorme potencial no desenvolvimento de novos biofungicidas e tratamentos biotecnológicos. Os mais interessantes resultados foram obtidos na inibição de $B$. dothidea, $P$. viticola e Calosphaeria sp.

PALAVRAS-CHAVE: fitopatógenos fúngicos, doenças de frutas e videiras, musgo, hepáticas, química natural

\section{REFERENCES}

ALAM A.; SHARMA S. C.; SHARMA V. In vitro antifungal efficacies of aqueous extract of Targionia hypophylla L. against growth of some pathogenic fungi. Journal of Ayurvedic and Herbal Medicine, v. 2, n. 2, p. 229-233, 2011.

BEIKE A. K.; DECKER E. L.; FRANK W.; LANG D.; VERVLIET- SCHEEBAUM M.; ZIMMER A. D.; RESKI R. Applied Bryology - Bryotechnology. Tropical Bryology v. 31, p. 22-32, 2010.

COLLA P.; GILARDI G.; GULLINO M. L. A review and critical analysis of the European situation of soilborne disease management in the vegetable sector. Phytoparasitica, v. 40, n. 5, p. 515-523, 2012. https://doi.org/10.1007/s12600-012-0252-2

DAVEY M. L.; CURRAH R. S. Interaction between moss (Bryophyta) and fungi. Canadian Journal of Botany, v. 84, n. 10, p. 1509-1519, 2006. https://doi.org/10.1139/b06-120

DÖBBELER P. Biodiversity of bryophilous ascomycetes. Biodiversity and Conservation, v. 6, n. 5, p. 721738, 1997. https://doi.org/10.1023/A:1018370304090

ELAD Y.; KATAN J.; CHET I. Physical, biological, and chemical control integrated for soilborne diseases in potatoes. Phytopathology, v. 70, n. 5, p. 418-422, 1980.

EYLES A.; BOUND S. A.; OLIVER G.; CORKREY R.; HARDIE M.; GREEN S. \& CLOSE D. C. Impact of biochar amendment on the growth, physiology and fruit of a young commercial apple orchard. Trees, v. 29, n. 6, p. 1817-1826, 2015. https://doi.org/10.1007/s00468-015-1263-7

GAMLIEL A.; AUSTERAWEIL M.; KRITZMAN M. Nonchemical approach to soilborne pest management: Organic amendments. Crop Protection, v. 19, n. 8-10, p. 847-853, sep.2000. https://doi.org/10.1016/S02612194(00)00112-5

GLIME J. M. Bryophyte ecology. 2017. [accessed in Oct. 2018]. Available in: https://digitalcommons.mtu.edu/bryophyte-ecology

GOGA M.; RUCOVA D.; KOLARCIK V.; SABOVLJEVIC M.; BACKOR M.; LANG I. Usnic acid, as a biotic factor, changes the ploidy level in mosses. Ecology and Evolution v. 8, n. 5, p. 2781-2787, 2018. https://doi.org/10.1002/ece3.3908

GRGIC S.; COSIC J.; REBEKIC A.; VRANDECIC K. Impact of essential oils on mycelial growth of Botrytis cinerea. Agriculture, v. 22, n. 2,p. 29-33, 2016. https://doi.org/10.18047/poljo.22.2.5 
GUETSKY R.; SHTIENBERG D.; ELAD Y.; FISCHER E.; DINOOR A. Improving biological control by combining biocontrol agents each with several mechanisms of disease suppression. Phytopathology, v. 92, n. 9, p. 976-985, 2002. https://doi.org/10.1094/PHYTO.2002.92.9.976

SABOVLJEVIC A.; SOKOVIC M.; GLAMOCLIJA J.; CIRIC A.; VUJICIC M.; PEJIN B.; SABOVLJEVIC $\mathrm{M}$. Comparison of extract bio-activities of in situ and in vitro grown selected bryophyte species.

African Journal of Microbiology Research, v. 4, n. 9, p. 808-812, 2010.

SABOVLJEVIC A.; SOKOVIC M.; GLAMOCLIJA J.; CIRIC A.; VUJICIC M.; PEJIN B.; SABOVLJEVIC M. Bio-activities of extracts from some axenically farmed and naturally grown bryophytes. Journal of Medicinal Plant Research, v. 5, n. 4, p. 565-571, 2011.

SABOVLJEVIC M. S.; SABOVLJEVIC A. D.; IKRAM N. K. K.; PERAMUNA A.; BAE H.; SIMONSEN H. T. Bryophytes - an emerging source for herbal remedies and chemical production. Plant Genetic Resources, v. 14, n. 4, p. 314-327, 2016. https://doi.org/10.1017/S1479262116000320

SABOVLJEVIC M. S.; VUJICIC M.; WANG X.; GARRAFFO M.; BEWLEY C. A.; SABOVLJEVIC A. Production of the macrocyclic bis-bibenzyls in axenically farmed and wild liverwort Marchantia polymorpha L. subsp. ruderalis Bischl. et Boisselier. Plant Biosystems, v. 151 n. 3, p. 414-418, 2017. https://doi.org/10.1080/11263504.2016.1179692

SABOVLJEVIĆ A.; SOKOVIĆ M.; SABOVLJEVIĆ M.; GRUBIŠIĆ D. Antimicrobial activity of Bryum argenteum. Fitoterapia, v. 77, n. 2, p. 144-145, 2006. https://doi.org/10.1080/11263504.2016.1179692

SINGH S.; SRIVASTAVA K.; KHANNA D. R. Potential of Plagiochasma appendiculatum on inhibition of certain economically important plant pathogens. Biological Forum, v. 2, n. 2, p. 122-129, 2010.

SRIVASTAVA N. Funaria hygrometrica extracts with activity against plant pathogenic fungi Alternaria species. ESSENCE - International Journal for Environmental Rehabilitation and Conservation, v. 6,n. 2, p. $105-112,2015$.

TADESSE M.; STEINER U.; HINDORF H.; DEHNE H-W. Bryophyte extracts with activity against plant pathogenic fungi. Ethiopian Journal of Science, vol. 26, n. 1, p. 55-62, 2003.

VAN HOOF L.; DERGHE D. A. V.; PETITE E.; VLIETINK A. J. Antimicrobial and antiviral screening of Bryophyta. Fitoterapia, v. 52, p. 223-230, 1981.

VOLLÁR M.; GYOVAI A.; SZÜCS P.; ZUPKÓ I.; MARSCHALL M.; CSUPOR-LÖFFLER B.; BÉRDI P.; VECSERNYÉS A.; CSORBA A.; LIKTOR-BUSA E.; URBÁN E.; CSUPOR D. Antiproliferative and antimicrobial activities of selected bryophytes. Molecules, v. 23, n. 7, n. 1520, 2018.

https://doi.org/10.3390/molecules23071520

WOLTERS A. Die Verbreitung antifungaler Eigenschaften bei Moosen. Planta, v. 62, n. 1, p. 88-96, mar. 1964. https://doi.org/10.1007/BF01900571

YAYINTAS O. T.; ALPASLAN D.; YUCEER Y. K.; YILMAZ S.; SAHINER N. Chemical composition, antimicrobial, antioxidant and anthocyanin activities of mosses (Cinclidotus fontinaloides (Hedw.) P. Beauv. and Palustriella commutata (Hedw.) Ochyra) gathered from Turkey. Natural Product Research, v. 31, n. 18, p. 2169-2173, 2017. https://doi.org/10.1080/14786419.2016.1277355 